Special issue of the SAJHE: 30(3) 2016

\title{
REVITALISING CAREER COUNSELLING TO FOSTER CAREER ADAPTABILITY AND RESILIENCE DURING CHANGE AND TURBULENCE
}

\author{
J. G. Maree \\ Department of Educational Psychology \\ University of Pretoria \\ Pretoria, South Africa \\ e-mail: kobus.maree@up.ac.za
}

The $21^{\text {st }}$ century workplace - defined largely by the economic global meltdown in 2008 - is characterised by fundamental change and turbulence at a time when 'the digital revolution produces jobless work’ (Savickas 2011a, 6). One way to address this situation is to update career counselling theory and practice. Career counselling theorists, practitioners, and researchers need to join hands to meet the career counselling requirements of their clients, including improving their career adaptability, helping them become (more) employable, and strengthening their career resilience. An active, positive approach to career counselling can help workers navigate repeated transitions in the midst of uncertainty, impermanence, despair, and the disappearance of structures that previously upheld a holding environment in the workplace. Hope must be restored in the hearts and minds of current and future employees, and decent work must be made accessible to all work seekers. According to the United Nations (UN 2006, 85): 'The Decent Work Agenda promotes access for all to freely chosen employment, the recognition of fundamental rights at work, an income to enable people to meet their basic economic, social and family needs and responsibilities and an adequate level of social protection for workers and their family members' (a definition adopted by the International Labour Organization in 1999). Decent work thus entails productive work for all workers in work environments that promote freedom, equity, security, and human dignity.

As stated previously, the key to survival in highly competitive job markets is adaptability, employability, and resilience, and this can best be achieved through the ongoing upskilling of career counsellors to enable them to instill these qualities in clients. An integrated qualitative + quantitative approach to career counselling can give counsellors the theoretical foundation to 
establish 'best practice' in the interests of clients. This entails helping them choose appropriate careers, find meaningful work, successfully negotiate short- or long-term assignments, construct themselves adequately, design successful lives, and make meaningful social contributions.

The international, transdisciplinary, and interdisciplinary contributions in this guest issue cover developments in career counselling that can help career counselling professionals anticipate future trends in the world of work. Individually, the contributions reflect individual authors' dedication and research acumen, and, collectively, they reflect a wide array of perspectives on important issues in $21^{\text {st }}$ century career counselling. The contributions, cast in a predominantly qualitative research tradition, contribute significantly towards a 're-view' of career theory and techniques. The contributions are discussed briefly in the same order in which they appear in this special issue

In the first article, 'All's well that ends': Concluding a deanship, Irma Eloff (2016) adopts a self-guided process of writing based on the Schlossberg model for career transition. She shows how self-reflective writing can contribute to successful personal navigation in the final phase of an academic leadership position. In contributing to the scant literature on the exit phases of such a position, Eloff highlights the ability of narrative career counselling to facilitate narratability and the potential of autobiographicity to support career transition.

In the second article (the first international contribution), Reflective career dialogues, Frans Meijers and Reinekke Lengelle (2016) state that universities are increasingly investing in career guidance in order to meet the numerous challenges brought about by the individualisation of society and the 'flexibilisation' of employment relationships. Arguing that managers generally have little vision concerning guidance and counselling, the authors call for an approach that will help students develop a career identity (defined as a story about the meaning of their lives) and thus obtain a sense of self-directedness and also do well in university contexts that tend to be 'disembodied' places with little opportunity for emotional expression.

In the third article, Enabling resilience: Shifting the intergenerational career expectations of South Africans challenged by structural disadvantage, Linda Theron (2016) contends that disadvantaged South African adults often advise impressionable young people to invest in an academic education that will lead to lucrative careers. Young people (especially those who do not have access to career counselling) are often influenced by such intergenerational social expectations, which can be dangerous, particularly when their dreams can easily come to naught because of the structural impediments they face. The author sensitises career counsellors to this situation and proposes that they modify young people’s career knowledge and intergenerational 
career expectations accordingly.

In the fourth contribution (the second international contribution), Supporting student transitions: Integrating life design, career construction, happenstance, and hope, Jackie PeilaShuster (2016) discusses an integrated eclectic theoretical approach aimed at facilitating student transitions to their professional career-lives. Arguing that the life design paradigm anchors the integration of career construction theory, the happenstance learning theory, and the hope theory, she applies these theories to the $4 \mathrm{~S}$ transition model in an attempt to give some guidance to career counsellors who work with students. She maintains that career counsellors should partner with students (in higher education environments) to help them deal with the myriad career-life transitions they will face during their career-lives.

In the fifth article, An interplay of self-efficacy in pursuit of a tertiary qualification: A case study of a black male, Dinah Alexander (2016) examines the perceptions of a middle-aged South African male from a disadvantaged background on his pursuit of a higher education qualification. Using narrative inquiry and a semi-structured interview schedule, Alexander identifies external and internal barriers perceived by the participant to influence his quest for a higher education qualification. The participant later confirmed the helpfulness of the postmodern career counselling intervention used in the study.

Tumi Diale, in the sixth article, Life Orientation teachers' career development needs in Gauteng: Are we missing the boat?, contends that the changes in the Life Orientation (LO) curriculum in South Africa over the past two decades have left LO teachers feeling swamped by the complex nature of the subject. The study on which this article is based involved Gauteng teachers and sought to add to the body of knowledge on the subject. The data analysis confirmed the urgent need for the formal training and support of LO teachers.

Anouk Albien and Anthony Naidoo (2016), in the seventh contribution, Social career influences of Xhosa adolescents elicited using the systems theory framework in a peri-urban South African township, examine the major influences on the career decision-making processes of Xhosa-speaking learners in a peri-urban township (e.g. family, school, and peer relationships; media role models; and cultural factors). The authors explore also Afrocentric narratives of overcoming hardship and adversity and conclude that reconciliation of 'Western' career aspirations with rural cultural expectations is a key challenge in black adolescents' vocational identity development.

In the eighth article, The value of the gap year in the facilitation of career, Stephan Rabie and Anthony Naidoo (2016) investigate the gap year experience of 11 first-year Stellenbosch University students and examine its influence on the development of their adaptive career 
resources and preparedness. The authors identified, on the basis of phenomenological analysis, a number of themes and subthemes that indicated that the gap year promoted formative personal growth as well as the acquisition of a variety of skills by the participants. Increased career maturity, combined with better knowledge of the world of work, appeared to enable the participants to construct a more confident identity and make informed career decisions.

Lourens and Monja Human (2016), in the ninth article, The usefulness of facilitating narrative career counselling with learner-athletes in a South African sport school, investigate the value of administering narrative career counselling to learner-athletes in a South African sports school as opposed to administering traditional career counselling in relative isolation. Involving three participants from disadvantaged environments, and drawing on narrative career counselling, the authors found evidence of the usefulness of such counselling in ensuring that neither of the dual roles of learner-career or athlete-career took precedence over the other.

This guest issue concludes with Kobus Maree's (2016) article, Career construction as a way of resolving career indecision, in which he reports on the value of career construction counselling for a woman beset with indecision about her career future. Using the Career Construction Interview (CCI) to collect qualitative data, and following Savickas' (2011a, 2011b) eight-step strategy to complete the participant's life portrait, the author concludes that the career construction intervention used in the study helped her clarify and resolve her career indecision. He calls also for further research on career construction counselling in different contexts and on its longer term impact.

In conclusion, we hope readers will find the various contributions useful and thought provoking. We thank prof Yusef Waghid, editor-in-chief of the SAJHE, for arranging this special issue of the journal, the editorial team (Ms Anèl Uys and Ms Gerda Scholtz in particular) for their professional input, and the reviewers for their selfless and timeous review of the manuscripts.

\section{REFERENCES}

Albien, A. and A. V. Naidoo. 2016. Social career influences of Xhosa adolescents elicited using the systems theory framework in a peri-urban South African township. South African Journal of Higher Education 30(3): 111-137.

Alexander, D. 2016. An interplay of self-efficacy in pursuit of a tertiary qualification: A case study of a black male. South African Journal of Higher Education 30(3): 67-83.

Diale, T. 2016. Life Orientation teachers' career development needs in Gauteng: Are we missing the boat? South African Journal of Higher Education 30(3): 84-110.

Eloff, I. 2016. ‘All’s well that ends': Concluding a deanship. South African Journal of Higher Education 30(3): 6-20.

Human, L. and M. Human. 2016. The usefulness of facilitating narrative career counselling with learner- 
athletes in a South African sport school. South African Journal of Higher Education 30(3): 156169.

IOL, see International Labour Organization.

International Labour Organization. 1999. Report of the Director-General: Decent work. International Labour Conference, $87^{\text {th }}$ Session, Geneva. http://www.ilo.org/public/english/standards/relm/ ilc/ilc87/rep-i.htm

Maree, J. G. 2016. Career construction as a way of resolving career indecision. South African Journal of Higher Education 30(3): 170-192.

Meijers, F. and R. Lengelle. 2016. Reflective career dialogues. South African Journal of Higher Education 30(3): 21-35.

Peila-Shuster, J. 2016. Supporting student transitions: Integrating life design, career construction, happenstance, and hope. South African Journal of Higher Education 30(3): 53-66.

Rabie, S. and A. V. Naidoo. 2016. The value of the gap year in the facilitation of career. South African Journal of Higher Education 30(3): 138-155.

Savickas, M. L. 2010. Re-viewing scientific models of career as social constructions. Revista Portuguesa de Pedagogia Psychologica, Numero Conjunto Comemorativo 30: 33-43.

Savickas, M. L. 2011a. New questions for vocational psychology: Premises, paradigms, and practices. Journal of Career Assessment, DOI: 10.1177/1069072710395532.

Savickas, M. L. 2011b. Career counseling. Washington, DC: American Psychological Association.

Savickas, M. L. 2013. The theory and practice of career construction. In Career development and counseling: Putting theory and research to work, ed. S. D. Brown and R. W. Lent, 147-186. 2nd edition. Hoboken, NJ: Wiley.

Theron, L. 2016. Enabling resilience: Shifting the intergenerational career expectations of South Africans challenged by structural disadvantage. South African Journal of Higher Education 30(3): 36-52.

United Nations UN. 2006. Full and productive employment and decent work. New York, NY: United Nations. http://www.un.org/en/ecosoc/docs/pdfs/ecosoc_book_2006.pdf 